\title{
Intellectual Property Rights, Imitative Ability and Export Performance: The Korean Experience*
}

\author{
YOON HEO ${ }^{* *}$ AND NGUYEN K. DOANH ${ }^{* * *}$
}

\begin{abstract}
This paper investigates the impacts of IPR protection in foreign countries on Korea's export performance. The empirical analysis in this paper differs from those in previous studies in several respects. First, the impact of IPRs is firstly forced to be uniform across sectors and then is allowed to differ across sectors so that industry-specific evidence can be documented. Second, in order to analyze the impact of IPR protection on trade, we employ the random-effects model to incorporate differences between cross-sectional entities by allowing the intercept to change, but the amount of change is random. Third, the study is based on an analysis of the most recent panel data which allow the patent regime to change over time. Finally, this study provides new evidence regarding the linkage between IPRs and trade with a focus on Korea. Our major findings are summarized as follows. First, reinforced IPR protection in foreign countries has a positive effect on Korea's total exports, indicating the dominance of market expansion effects. Second, stronger protection of IPRs induces Korea's exports to all foreign countries regardless of their level of development. The effects are stronger in medium-income and high-income countries. Third, Korea tends to export more to countries with strong imitative ability when the IPR protection in those countries is strengthened. Finally, stronger protection of IPRs in foreign countries with weak imitative ability leads to an ambiguous reduction in Korea's exports. Efforts to increase the GDP, improve social infrastructure, accelerate domestic reforms (openness to trade), and strengthen IPR protection in foreign countries are suggested as a remedy for obstacles to Korea's exports. Importantly, strengthening of IPRs would have the greatest effect if foreign GDP also rose.
\end{abstract}

Keywords: IPRs, Korea, Gravity Model, Random Effects, Panel Data, Trade Flows

An earlier version of this paper was presented at SOGANG IIAS RESEARCH SERIES ON INTERNAIONAL AFFAIRS, 2011. This research was supported by Special Research Grant of Sogang University (2011-10075.01).

** Professor of International Trade, Graduate School of International Studies, Sogang University, Seoul, Korea, zip code: 121-742. Tel: 0082-2-705-8948; Fax: 0082-2-705-8755; E-mail: hury@sogang.ac.kr Associate professor, Dean of Graduate School, Thai Nguyen University of Economics and Business Administration, Thai Nguyen City, Vietnam; Tel: 0084-977-242-268; Fax: 0084-280-647 684. E-mail: nkdoanh@yahoo.com 


\section{INTRODUCTION}

$\mathrm{O}$

ver the past decade, the protection of intellectual property rights (IPRs) has become one of the most important issues in the international economy. Indeed, economists have recognized that the protection of IPRs has a significant impact on trade flows (Segerstrom et al. 1990; Grossman and Helpman 1991; Helpman 1993). The preliminary conjecture is that weak IPR protection distorts natural trade patterns and the ability of firms to transfer technology abroad. Thus, differences in national norms regarding IPR protection are thought to negatively affect freer flows of international trade. This could be one of the reasons why the regulation of national regimes of IPRs has recently become a contentious issue. Disputes over IPRs during the 1980s led to numerous initiatives to harmonize and strengthen IPRs at both national and international levels. The resulting Agreement on Trade-Related Aspects of Intellectual Property Rights (TRIPS) of 1994 represents the most far-reaching multilateral agreement toward global harmonization of IPRs.

Theoretically, economic analysis is unable to predict the direction of the impacts of IPR protection on bilateral trade flows. ${ }^{1}$ The existence of such ambiguity is because the strengthening of IPRs would simultaneously create two effects working in opposite directions (see, for example, Schwartz 1991; Taylor 1993, 1994; Maskus and Penubarti 1995; Smith 1999). Stronger protection of IPRs in importing countries allows foreign exporters to behave more monopolistically and choose to serve the export market by foreign direct investment or licensing their intellectual assets to a foreign firm (Ferrantino 1993; Lee and Mansfield 1996; Maskus 1998; Seyoum 1996), which is known as the market power effect. Simultaneously, a stronger level of IPR protection in importing countries encourages foreign exporters to export more to the foreign market due to the shrinkage of imitative activities in the importing countries, which is known as the market expansion effect.

Since these two effects are offsetting, no clear prediction can be made regarding the nature and direction of the impacts of IPR protection on trade. This theoretical ambiguity regarding the impact of IPR protection on international trade has led to several empirical attempts. Recently, a growing body of literature on the nature and direction of the effects of IPR protection on international trade flows has suggested that the relationship between IPRs and trade cannot be generalized (see Maskus and Penubarti 1995; Fink and Primo-Braga 2005; Smith 1999, 2002; Rafiquzzaman 2002). The results of these studies show that the impact of stronger protection of IPRs on trade is an empirical issue. This has induced us to concentrate on an empirical analysis of the issue in the Korean case. We choose Korea as the case study because of the following reasons. First, Korea is an export-oriented economy where the impacts of IPR protection are rarely documented. Second, Korea is located between a developed and a developing 
country, which can provide richer insights on the subject. Finally, the percentage of IPR-sensitive high-tech exports relative to Korea's total exports has been increasingly high.

\section{RESEARCH OBJECTIVE}

This study aims at promoting an understanding of IPR protection and its impacts on international trade, taking Korea as a case study. Therefore, it is guided by the following specific objectives:

- To analyze the impacts of IPR protection in foreign countries on Korea's total exports and exports by commodity.

- To analyze the impacts of IPR protection in foreign countries with different income levels on Korea's total exports and exports by commodity.

- To derive useful policy implications based on the estimated results.

The empirical analysis in this paper differs from those in previous studies in several respects. First, the impact of IPRs is firstly forced to be uniform across sectors and then is allowed to differ across sectors so that industry-specific evidence can be documented. ${ }^{2}$ Second, in order to analyze the impact of IPR protection on trade, we use the random-effects model. The advantage of this model is that both time-series and cross-sectional variations are used. Third, this study provides new evidence regarding the linkage between IPRs and trade with a focus on Korea by using the most recent panel data, which allow the patent regime to change over time. ${ }^{3}$ Finally, to measure the status of an IPR regime, the IPR index developed by Park and Ginarte (1997) is used.4

\section{THEORETICAL FRAMEWORK}

The linkage between IPR protection and trade has been discussed at length in the literature (see, for example, Flam and Helpman 1987; Maskus and Penubarti 1997). Although it is unambiguous that IPR protection can influence trade flows, the net impact on trade flows of strengthening the protection of IPRs remains theoretically ambiguous (Maskus 2000; Maskus and Penubarti 1995). Naturally, the importance of these effects is likely to depend on specific product and market characteristics. Certainly, some products are easier to imitate than others, and some products have closer substitutes than others. In addition, the impacts of IPR protection also depend on exporters. If an exporter is not an innovator, the imports from this exporter's country are less likely to be new technology-intensive. Hence, the protection of IPRs is not important for trade in this case. 
The observation that extant theory indicates that the relationship between stronger IPR protection and trade could have either sign has led to attempts to resolve this ambiguity empirically. To date, a number of studies have attempted to estimate the effects of IPR protection (see Al-Mawali 2005; Wen-Hsien and Ya-Chi 2005). Maskus and Penubarti (1995) provided the first systematic evidence of the linkage between IPRs and trade, and demonstrated that national differences in IPRs distort trade flows. They found that stronger protection of IPRs increases trade flows, that is, the market expansion effect tends to dominate the market power effect, when all industries are pooled. Jung (2007) found similar results-that is, foreign protection of IPRs have the market expansion effects on total IT exports of Korea. This result is consistent with Oh and Won (2005), who found that Korea tends to export more to the trading partners where their patents are highly protected.

Other studies have emphasized the level of development in analyzing the impacts of IPR protection on trade. For example, Smith (1999) introduced interaction terms that are the product of interactions between IPRs and four dummy variables based on the per-capita income of the importers, including low income, lower middle income, upper middle income, and high income. Smith found that U.S. exporters respond positively to the strength of IPR protection in countries classified as low middle-income countries, but negatively to that in other country groups. Rafiquzzaman (2002) used a similar methodology to construct three development dummy interaction variables. These variables are the products of interaction between IPRs and development dummies, which are constructed by classifying the importing countries into three groups by their level of economic development: high income, middle income and low income. The results showed that at the aggregate manufacturing level, Canadian exports respond positively to the strength of IPRs in countries within all levels of development groups.

Unlike the findings of Rafiquzzaman (2002), Kang and Park (2006) used the gravity model to investigate the impacts of foreign IPRs on Korea's exports from 2001 through 2003, divided by trading partners and industries. Their findings showed that the IPR level in foreign countries has negative effects on Korea's total exports. However, the effects of IPRs are negative in the export to developing countries and low-tech industries exports, but positive in the high-tech industries exports to developed countries.

Recently, Yang and Huang (2009) used a dynamic panel approach to analyze the sensitivity of Taiwan's exports to national differences in intellectual property right protection and the degree of imitation threat. Their empirical findings show that a stronger enforcement of the protection of IPRs in the importing countries induces Taiwan's exports, indicating the dominance of market expansion effects. However, the pattern of the relationship between threat of imitation and trade is contrary to the theory predictions. Falvey et al. (2009) employed panel data to analyze the impact of IPR protection on trade with a focus on 
the level of development, imitative ability and market size of the importing countries. They found that the market expansion effects are prevalent. For countries with low imitative abilities, strengthening low IPRs will result in market expansion effects for most industries. For countries with high imitative abilities there is a clear separation of industries. Those which exhibit market power effects when imitative ability is low show no significant effects from strengthening IPRs when imitative ability is high. Those which exhibit market expansion effects when imitative ability is low, exhibit market expansion effects when imitative ability is high.

A review of the previous literature on the subject leads to the following conclusions. First, theoretically, there is a link between IPRs and trade flow. However, the nature and the direction of the impact are ambiguous, depending on the interaction between market expansion and market power effects. Second, empirically, evidence on the linkage is mixed, which suggests that the impact of IPR protection on trade flows is an empirical issue and can only be assessed on a case-by-case basis. Third, past empirical evidence showed that industrial countries with relatively weak IPR regimes tend to import more when their IPR regimes are strengthened. 5 In contrast, in underdeveloped and developing countries with weak patent rights and weak imitative capacities, the market-power effect tends to dominate. 6 Finally, the response of trade in $\mathrm{R} \& \mathrm{D}$ intensive products to increased IPR protection may be difficult to predict. The reason is that these products are particularly difficult to imitate anyway, and the producers of these products might choose to serve foreign countries through FDI and licensing. These hypotheses are among those being explored further below.

\section{EMPIRICAL MODEL}

\section{Model Specification}

The topic being explored is most suited to a quantitative approach. In seeking to empirically estimate the impacts of increased IPR protection on trade flows, a gravity model is adopted. The gravity model is commonly applied in the international trade literature to analyze trade distortions associated with policy differences across countries. For estimation purposes, the gravity model is expressed in log-linear form as follows:

$$
\begin{aligned}
\ln \left(1+\mathrm{E}_{\mathrm{ijt}}\right)= & \beta_{0}+\beta_{1} \operatorname{lnGDP} \mathrm{it}_{\mathrm{it}}+\beta_{2} \operatorname{lnGDP} \mathrm{Int}_{\mathrm{jt}}+\beta_{3} \ln \operatorname{lnOP}_{\mathrm{it}}+\beta_{4} \ln \operatorname{lnOP}_{\mathrm{jt}} \\
& +\beta_{5} \operatorname{lnDIST}_{\mathrm{ij}}+\beta_{6} \mathrm{OPEN}_{\mathrm{jt}}+\beta_{7} \mathrm{LOCK}_{\mathrm{j}}+\beta_{8} \mathrm{IPR}_{\mathrm{jt}}+\mathrm{e}_{\mathrm{ijt}}
\end{aligned}
$$

Where:

- $\mathrm{E}_{\mathrm{ijt}}$ is Korea's exports (country i's exports) to the importing country (country j) at time t. ${ }^{7}$ 
- $\mathrm{GDP}_{\mathrm{it}}$ is the gross domestic product (GDP) of Korea at time $t$.

- $\mathrm{GDP}_{\mathrm{jt}}$ is the gross domestic product (GDP) of the importing country at time $t$.

- $\mathrm{POP}_{\mathrm{it}}$ is the population of Korea at time $\mathrm{t}$.

- $\mathrm{POP}_{\mathrm{jt}}$ is the population of the importing country (country $j$ ) at time $t$.

- DIST $_{\mathrm{ij}}$ is the geographical distance, measured as the crow flies, between the capital city of Korea and the capital city of the importing country.

- $\mathrm{OPEN}_{\mathrm{jt}}$ is the openness to trade of the importing country at time $t$, measured as the dollar value of exports plus imports as a percentage of the gross domestic product (GDP).

- $\mathrm{LOCK}_{\mathrm{j}}$ is a dummy variable that equals 1 if the importing country is landlocked and zero otherwise.

- $\mathrm{IPR}_{\mathrm{jt}}$ is the IPR index of the importing country at time $t$.

- $\mathrm{e}_{\mathrm{ijt}}$ is an error term.

The gravity theory predicts that the parameters on GDP are positive (Chionis and Liargovas 2002; Frankel 1993). The coefficients on population could be either positive or negative. ${ }^{8}$ The distance between trading partners $\left(\right.$ DIST $_{\mathrm{ij}}$ ) is used as a proxy for several distance-related variables such as the transport cost, cost of time, "psychic distance" or "cultural cost," and access to relevant market information (Linenman 1966).9 Since countries with higher levels of openness tend to trade more, we expect that the coefficient on $\mathrm{OPEN}_{\mathrm{jt}}$ is positive $(\mathrm{Smith}$ 2001; Smith 2002). Being landlocked is generally considered to reduce international trade because the number of border-crossings can explain a major part of the extra cost of overland transport in comparison with maritime transport (Raballand 2003). Finally, the sign of the coefficient on the IPR index could be positive or negative.

Although the gravity equation, viz., (1), is able to analyze the sensitivity of Korea's exports to national differences in IPR protection, it is not able to capture whether or not this sensitivity is dependent on the importing country's level of economic development. Therefore, in order to capture this effect, we let the development dummy variables interact with IPRs. ${ }^{10}$ In this study, we construct the development dummy variables by classifying the importing countries in our sample into three groups by their level of economic development: high income $\left(\mathrm{HD}_{\mathrm{jt}}\right)$, middle income $\left(\mathrm{MD}_{\mathrm{jt}}\right)$, and low income $\left(\mathrm{LD}_{\mathrm{jt}}\right){ }^{11}$ For estimation purposes, Eq. (1) is re-written as follows:

$$
\begin{aligned}
\ln \left(1+\mathrm{E}_{\mathrm{ijt}}\right)= & \beta_{0}+\beta_{1} \operatorname{lnGDP} \mathrm{P}_{\mathrm{it}}+\beta_{2} \operatorname{lnGDP} \mathrm{P}_{\mathrm{jt}}+\beta_{3} \ln \mathrm{POP}_{\mathrm{it}}+\beta_{4} \ln \mathrm{POP}_{\mathrm{jt}} \\
& +\beta_{5} \operatorname{lnDIST} \mathrm{IIj}_{\mathrm{ij}}+\beta_{6} \mathrm{OPEN}_{\mathrm{jt}}+\beta_{7} \mathrm{LOCK}_{\mathrm{j}}+\beta_{8} \mathrm{IPR}_{\mathrm{jt}} \times \mathrm{LD}_{\mathrm{jt}} \\
& +\beta_{9} \mathrm{IPR}_{\mathrm{jt}} \times \mathrm{MD}_{\mathrm{jt}}+\beta_{10} \mathrm{IPR}_{\mathrm{jt}} \times \mathrm{HD}_{\mathrm{jt}}+\mathrm{e}_{\mathrm{ijt}}
\end{aligned}
$$

First, the regression equation with respect to Korea's total exports to the 
Rest of the World (ROW) is estimated. This means that by pooling panel data on exports, we force the impact of IPRs on Korea's exports to be uniform. After that, the regression model with respect to Korea's exports to ROW (classified by Korea's exports by commodity) is estimated. This means that we allow the impacts of IPR protection to differ across industries. The rationale for setting up different specifications is as follows. First, using the data of total exports allows us to see the overall impact of IPRs on exports regardless of the industry. Second, using the same gravity equation for different sectors allows us to capture the distinctive features of each sector in terms of IPR sensitivity.

Since we use the panel data for the research, we must choose between the fixed effects model and the random effects model. The fixed effects model allows for country-pair heterogeneity and gives each country-pair its own intercept. It is expressed as follows:

$$
\begin{aligned}
\ln \left(1+\mathrm{E}_{\mathrm{ijt}}\right)= & \beta_{0 \mathrm{ij}}+\beta_{1} \operatorname{lnGDP} \mathrm{P}_{\mathrm{it}}+\beta_{2} \operatorname{lnGDP} \mathrm{ln}_{\mathrm{jt}}+\beta_{3} \operatorname{lnPOP}{ }_{\mathrm{it}}+\beta_{4} \ln \mathrm{IOP}_{\mathrm{jt}} \\
& +\beta_{5} \operatorname{lnDIST} \mathrm{IIj}_{\mathrm{ij}}+\beta_{6} \operatorname{lnOPEN}_{\mathrm{jt}}+\beta_{7} \mathrm{LOCK}_{\mathrm{j}}+\beta_{8} \mathrm{IPR}_{\mathrm{jt}} \times \mathrm{LD}_{\mathrm{jt}} \\
& +\beta_{9} \mathrm{IPR}_{\mathrm{jt}} \times \mathrm{MD}_{\mathrm{jt}}+\beta_{10} \mathrm{IPR}_{\mathrm{jt}} \times \mathrm{HD}_{\mathrm{jt}}+\mathrm{e}_{\mathrm{ijt}} .
\end{aligned}
$$

Where, $\beta_{0 \mathrm{ij}}$ indicates that each country-pair has its own intercept. The fixed effects estimates can reduce potential specification errors from omitting important variables. One shortcoming of this model, however, is that it does not allow for time-invariant variables to be included.

Unlike the fixed effects model, the random-effects model incorporates differences between cross-sectional entities by allowing the intercept to change, but the amount of change is random. ${ }^{12}$ The random-effects model is expressed as follows:

$$
\begin{aligned}
\ln \left(1+\mathrm{E}_{\mathrm{ijt}}\right)= & \beta_{0}+\beta_{1} \operatorname{lnGDP} \mathrm{it}_{\mathrm{it}}+\beta_{2} \operatorname{lnGDP} \mathrm{In}_{\mathrm{jt}}+\beta_{3} \operatorname{lnPOP} \mathrm{P}_{\mathrm{it}}+\beta_{4} \operatorname{lnPOP} \mathrm{P}_{\mathrm{jt}} \\
& +\beta_{5} \operatorname{lnDIST}_{\mathrm{ij}}+\beta_{6} \operatorname{lnOPEN}_{\mathrm{jt}}+\beta_{7} \mathrm{LOCK}_{\mathrm{j}}+\beta_{8} \mathrm{IPR}_{\mathrm{jt}} \times \mathrm{LD}_{\mathrm{jt}} \\
& +\beta_{9} \mathrm{IPR}_{\mathrm{jt}} \times \mathrm{MD}_{\mathrm{jt}}+\beta_{10} \mathrm{IPR}_{\mathrm{jt}} \times \mathrm{HD}_{\mathrm{jt}}+\mathrm{w}_{\mathrm{ijt}} .
\end{aligned}
$$

Where, $\beta_{0}$ is the mean intercept, and $\mathrm{w}_{\mathrm{ijt}}$ is the composite error term $\left(\mathrm{w}_{\mathrm{ijt}}\right.$ $=\mu_{\mathrm{ij}}+\mathrm{u}_{\mathrm{ijt}}$ ), $\mu_{\mathrm{ij}}$ is a random unobserved bilateral effect (which is a cross-sectional or country-pair error component), and $\mathrm{u}_{\mathrm{ijt}}$ is the remaining error (which is the combined time-series and cross-sectional error component). ${ }^{13}$ The advantage of the random effects model is that it uses both time-series and cross-sectional variations.

The choice of the fixed effects model or the random effects model depends on the potential correlation between the explanatory variables and the error term. If the explanatory variables are correlated with the errors, the fixed effects model is more appropriate. In contrast, if the explanatory variables are not correlated with the errors, the random effects model is more appropriate. In this paper, we will rely on the Hausman test to decide which model is more 
appropriate.

\section{Data}

In this study, we use 1990, 1995, 2000, and 2005 data on Korea's exports (total exports and exports by commodity classified into 2-digit SITCs). Ninety-two importing countries are included in our sample, leading to 368 observations (Appendix 1). The data on Korea's exports, as measured in millions of US\$, come from the Korea International Trade Association (KITA) and UN Comtrade. GDP data, as reported in million US\$, are extracted from the IMF World Economic Outlook Database and the Economist Intelligence Unit. Population data, as reported in millions of people, are extracted from the IMF World Economic Outlook Database and the Economist Intelligence Unit. Distance data, as measured in kilometers, are collected from Indo.com (http://www.indo.com/distance/). Land-lock data comes from the Economist Intelligence Unit. The openness index is measured as the dollar value of exports plus imports as a percentage of gross domestic product (GDP). The classification of economies according to the level of income (level of development) is obtained from the World Bank's Classification.

Finally, to capture the effect of IPRs on bilateral trade flows, we use the IPR index. A number of studies have attempted to measure IPRs cross-nationally (Rapp and Rozek 1990; Seyoum 1996; Sherwood 1997). However, the IPR index developed by Park and Ginarte (1997), and later updated by Park (2008), is the most appropriate because it has the broadest country coverage. Moreover, it allows for a much more fine-tuned ranking of the national IPR system. ${ }^{14}$ Therefore, in this study, we use the IPR index developed by Park and Ginarte. As of now, the IPR index is compiled up to year 2005.

\section{ESTIMATED RESULTS}

\section{Basic Results}

A summary of statistics for the data used in the estimation is presented in Appendix 2. The basic results for the regression equation with respect to Korea's total exports to ROW are shown in Table 1. The first row shows the estimates of the coefficients for all industries. As indicated, the gravity model fits the data well, explaining a major part of the variation in bilateral trade. The conventional variables behave very much as the model predicts. All the estimated coefficients, except for $\mathrm{POP}_{i t}$ and $\mathrm{POP}_{i t}$, are statistically significant at the 0.05 significance level. The estimate of the intercept term at the aggregate level is negative and statistically significant, indicating that unmeasured trade distortions reduce Korea's exports. 


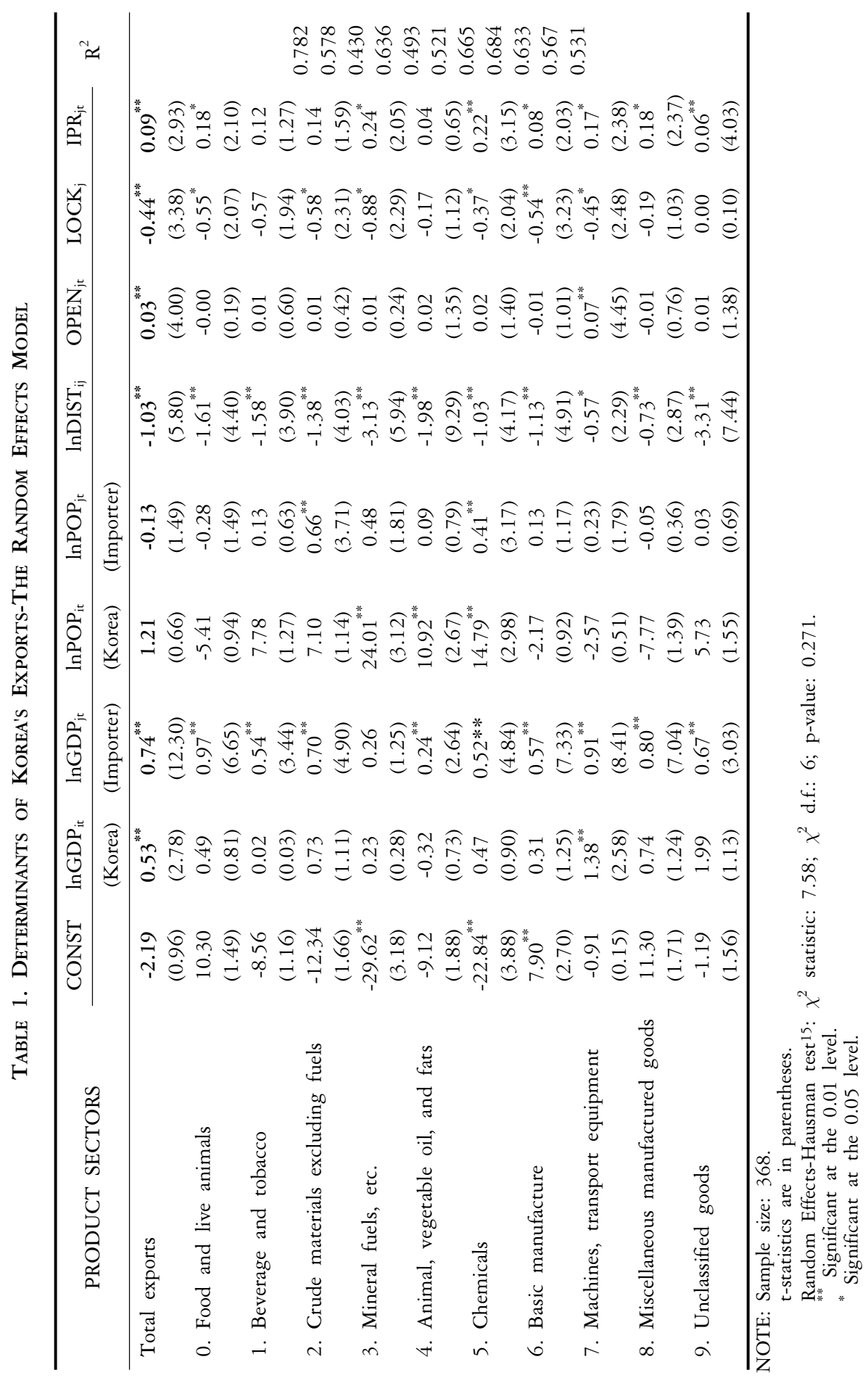


GDPs turn out to be important explanatory variables. The GDPs of both exporting and importing countries register positive impacts on bilateral trade, and the impacts are highly significant. The coefficient on $\mathrm{GDP}_{\text {it }}$ indicates that a one-percent increase in the GDP of the exporting country (Korea) increases the exporting country's exports by 0.53 percent. The coefficient on the importing country's GDP $\left(\mathrm{GDP}_{\mathrm{jt}}\right)$ is also positive with an elasticity of 0.74 .

The coefficient on $\mathrm{POP}_{\mathrm{it}}$ is positive, while the coefficient on $\mathrm{POP}_{\mathrm{jt}}$ is negative. However, both of them are statistically insignificant. This could be because the economies-of-scale effects are cancelled out by the absorption effects. We also found the customary negative signs on distance (DIST $\left.\mathrm{T}_{\mathrm{ij}}\right)$ and land-lock (LOCK $)$, and a positive sign on openness $\left(\mathrm{OPEN}_{\mathrm{jt}}\right)$.

Finally, our primary interest is in the impact of IPRs on Korea's exports. The coefficient on the patent rights index of the importing country $\left(\mathrm{IPR}_{\mathrm{jt}}\right)$ is positive and statistically significant. This indicates that, on average, stronger protection of IPRs in foreign countries does raise Korea's exports. Therefore, at the aggregate level, Korea tends to export more to countries with relatively strong IPR protection, supporting the view of market-expansion effects. This result is consistent with those of Maskus and Penubarti (1997), Smith (1999), Rafiquzzaman (2002), and Doanh and Heo (2007).

On the sectoral level (at the 1-digit level), it is clear that the above effects vary across sectors. As we observed, all the coefficients are positive, with the exception of Animal, Vegetable Oil, and Fat, for which an insignificant negative coefficient is found. The coefficients are statistically significant in such sectors as Food and Animals, Mineral Fuels, Chemicals, Basic Manufactures, Machines and Transport Equipment, Miscellaneous Manufactured Goods, and Unclassified Goods. We also found stronger effects of IPRs in such sectors as Mineral Fuels, Chemicals, Food and Animals, Miscellaneous Manufactured Goods, and Machines and Transport Equipment. This finding supports the view that in these industries, stronger protection of patent rights does enhance trade through market expansion. Thus, across all industries and countries, the exercise of enhanced market power does not play any role in reducing Korea's exports. At this point, we could conclude that the strengthening of IPR protection in foreign countries would raise Korea's exports to all countries.

\section{Results on Development Interaction}

In this section, we focus our analysis on the response of Korea's exports to the variation in the IPRs of foreign countries at similar levels of economic development. The effect is captured by the estimates of the interaction between IPRs and development dummy variables in Eq. (3). The development dummy variables are constructed by classifying the importing countries in our sample 
into three groups according to their level of economic development. These three groups include high-income countries $\left(\mathrm{HD}_{\mathrm{jt}}\right)$, middle-income countries $\left(\mathrm{MD}_{\mathrm{jt}}\right)$, and low-income countries $\left(\mathrm{LD}_{\mathrm{jt}}\right)$.

Table 2 displays the estimates of Eq. (3) that include the interactions of IPRs and the development dummy variables. The first row reports parametric estimates for aggregate exports, while the subsequent rows contain estimates for the disaggregated 1-digit level of the SITC product categories. According to the information in Table 2, at the aggregate level, the coefficients on traditional variables (GDP, distance, openness to trade, and landlocked status) have the expected signs and are statistically significant at the 0.01 level. Our results show that Korea tends to export more to countries with higher levels of GDP and openness, and export less to countries that are distant from Korea and landlocked.

As stated above, one of our major interests is on the impact of the variation in the strength of national IPRs in countries grouped by the level of economic development. As the results reveal, all the coefficients for the development dummy variables $\left(\mathrm{IPR}_{\mathrm{jt}} \times \mathrm{LD}_{\mathrm{jt}}, \mathrm{IPR}_{\mathrm{jt}} \times \mathrm{MD}_{\mathrm{jt}}\right.$, and $\left.\mathrm{IPR}_{\mathrm{jt}} \times \mathrm{HD}_{\mathrm{jt}}\right)$ are positive, and two them are statistically significant $\left(\mathrm{IPR}_{\mathrm{jt}} \times \mathrm{MD}_{\mathrm{jt}}\right.$ and $\mathrm{IPR}_{\mathrm{jt}} \times \mathrm{HD}_{\mathrm{jt}}$ ), exhibiting the market-expansion effects on Korea's exports to countries in all development groups. This result is consistent with that of Smith (1999). The effect is found to be stronger in high-income and middle-income countries. This indicates that Korea's exporters tend to respond positively to the strength of IPRs in foreign countries at all levels of development. In other words, IPRs have market-expansion effects on Korea's exports to all foreign countries regardless of their level of economic development. The effect is most prevalent in middle-income and high-income countries, followed by low-income countries.

At the sectoral level (1-digit level), the effects of the development dummy variables $\left(\mathrm{IPR}_{\mathrm{jt}} \times \mathrm{LD}_{\mathrm{jt}}, \mathrm{IPR}_{\mathrm{jt}} \times \mathrm{MD}_{\mathrm{jt}}\right.$, and $\left.\mathrm{IPR}_{\mathrm{jt}} \times \mathrm{HD}_{\mathrm{jt}}\right)$ vary across industries. As reported in Table 2 , the coefficients for the three development dummy variables are positive in nine out of ten sectors with the exception of Animal, Vegetable Oil, and Fat, for which an insignificant and negative coefficient is found. Within low-income countries, the effects of IPR protection appear to be relatively stronger in such sectors as Mineral Fuels, Chemicals, Miscellaneous Manufactured Goods, and Unclassified Goods. Within middle-income countries, stronger protection of IPRs in foreign countries has positive and significant effects on Korea's exports in seven product categories (Food and Live Animals, Mineral Fuels, Chemicals, Basic Manufacture, Machines and Transport Equipment, Miscellaneous Manufactured Goods, and Unclassified Goods). For the group of high-income countries, the coefficient on the development dummy interaction variable is positive and statistically significant in only two sectors (Food and Live Animals, and Unclassified Goods).

Table 3 reports the estimates of Eq. (3) (at the 2-digit level) for thirty sectors with the largest export volumes. For low-income countries, stronger protection of IPRs in foreign countries has a positive effect on Korea's exports in eighteen out of thirty sectors. However, the effects of IPR protection appear to be relatively stronger in such sectors as Fish, Petroleum, Plastics in Primary Forms, Plastics in Non-primary Forms, Leather, Prefabricated Buildings Sanitary, and Photographic 


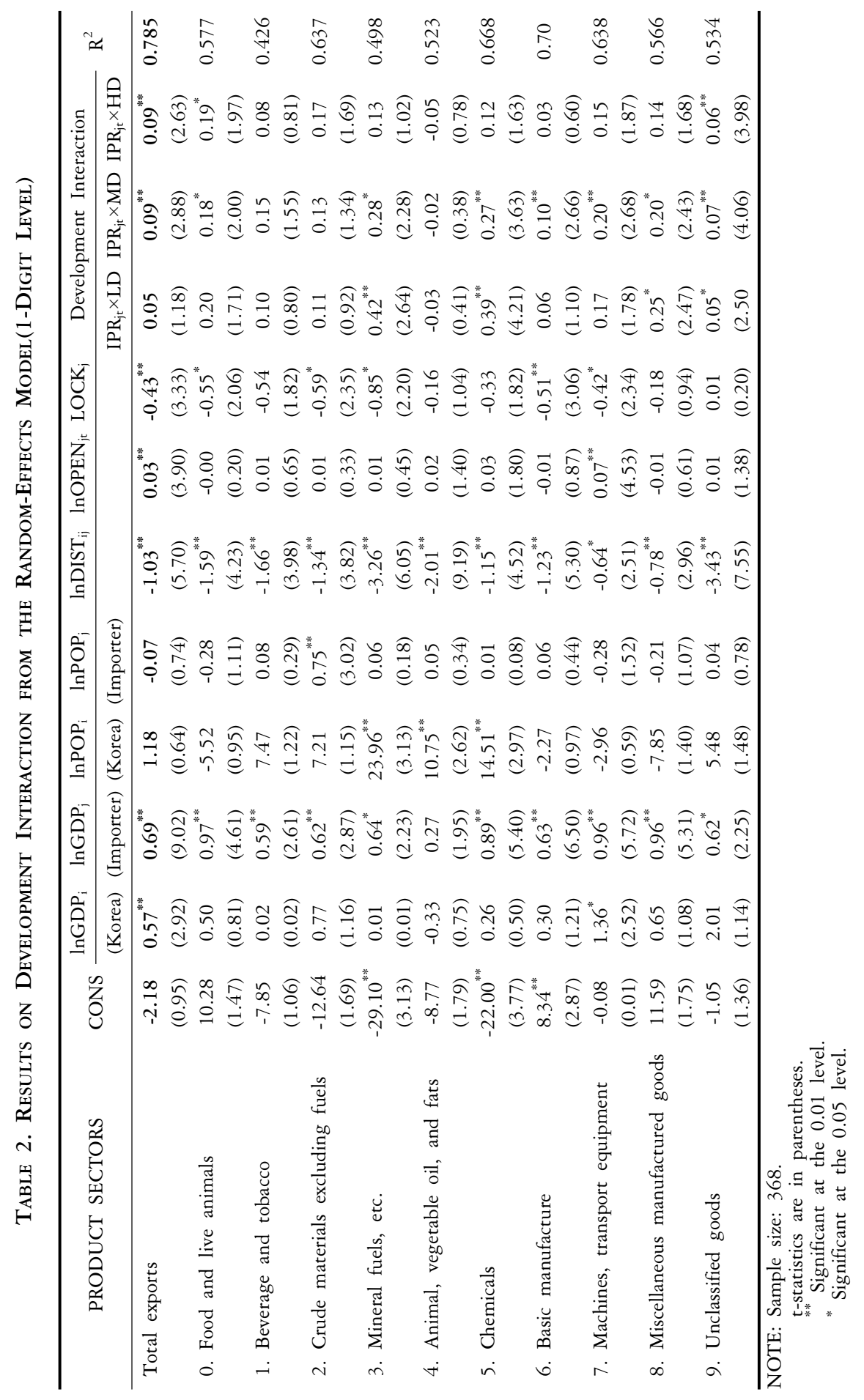




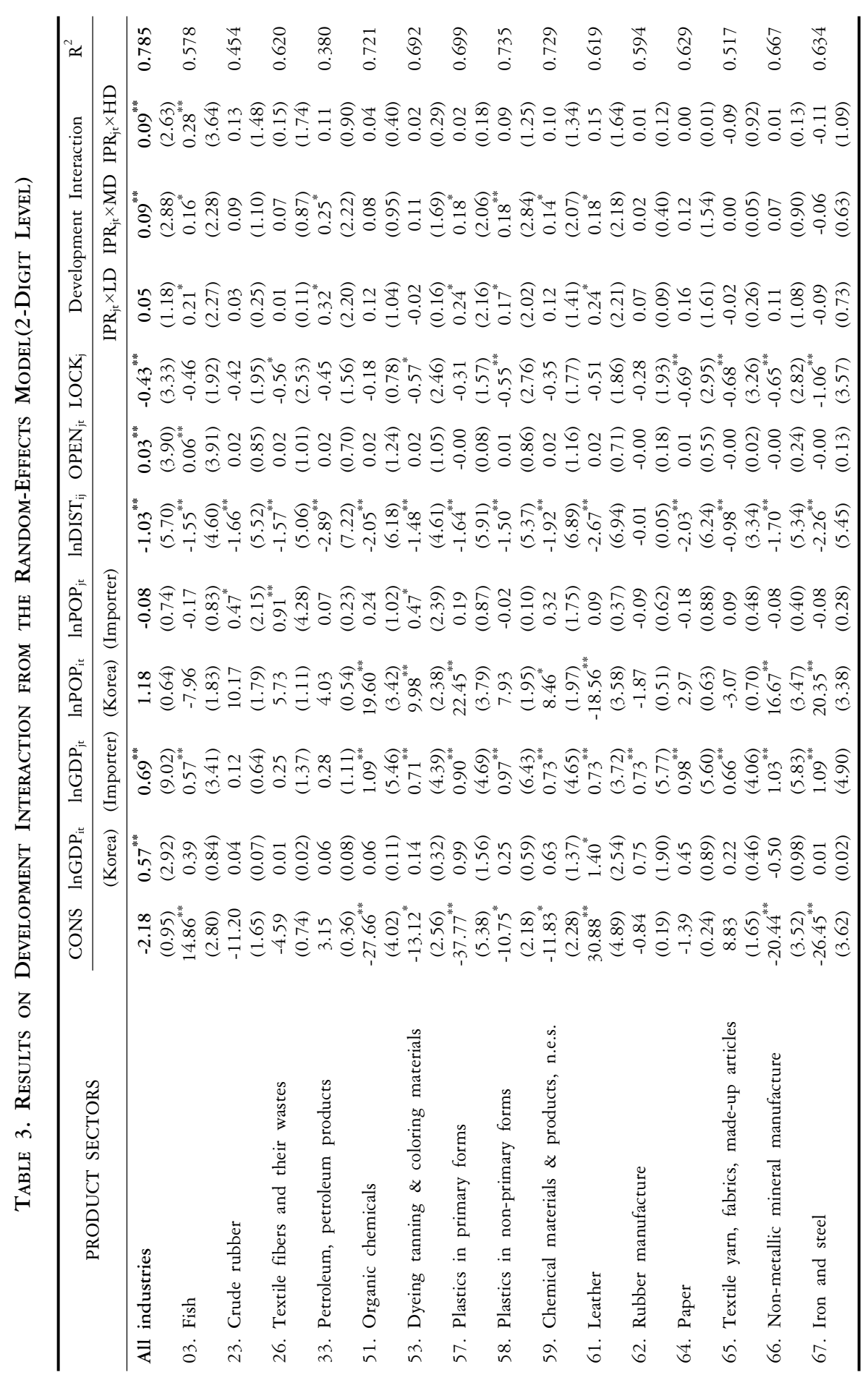




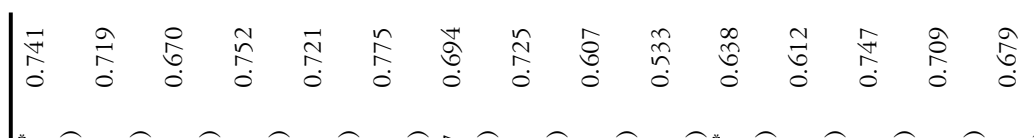

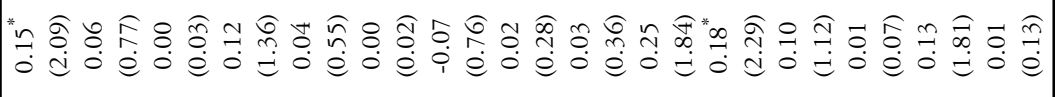

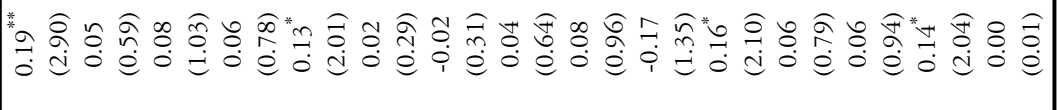

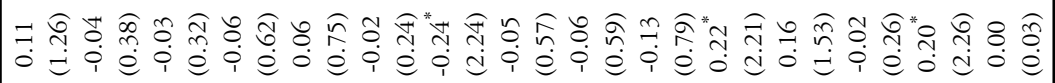

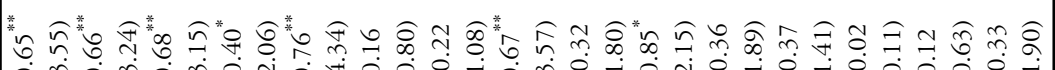

$$
\begin{aligned}
& \text { i n }
\end{aligned}
$$

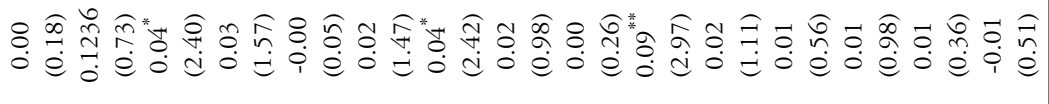

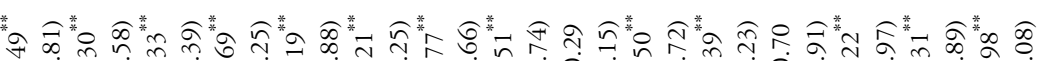

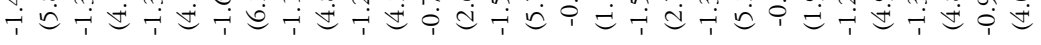

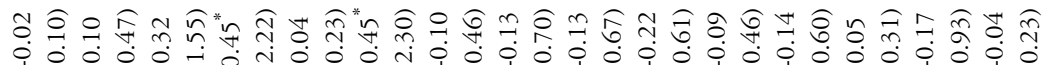

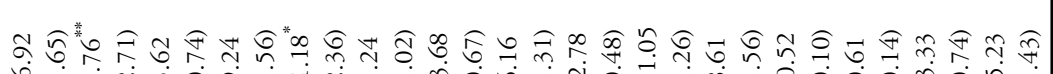

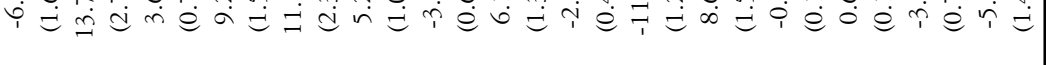

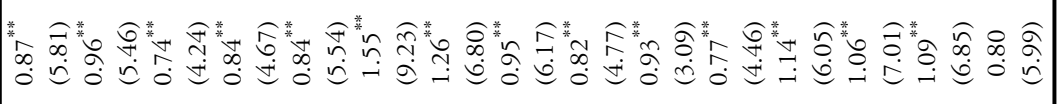

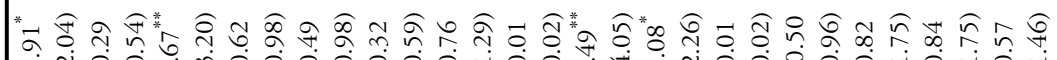

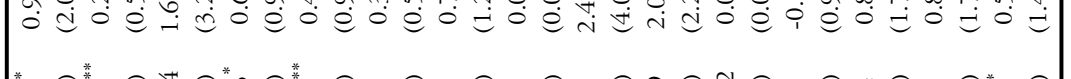

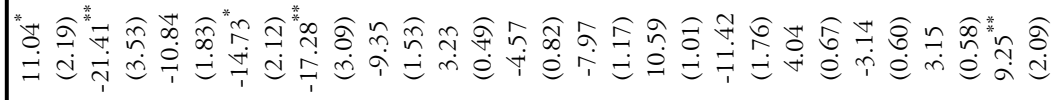

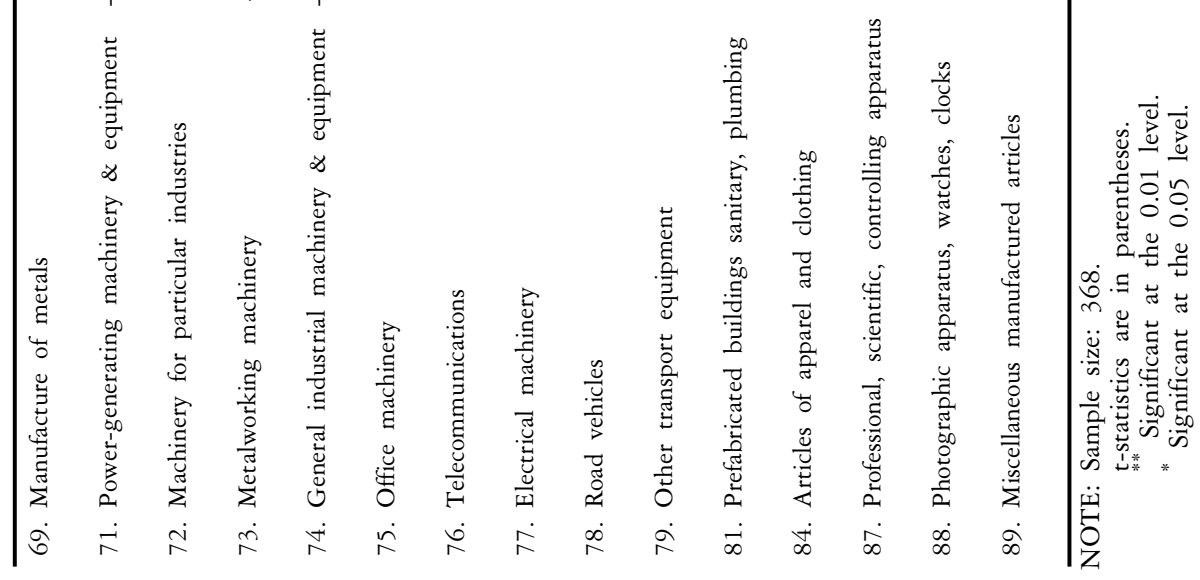


Apparatus. There are twelve sectors for which the coefficient on $\operatorname{IPR}_{\mathrm{jt}} \times \mathrm{LD}$ is negative, but is statistically significant in Sector 76 (Telecommunication). Although being statistically insignificant, negative parametric estimates could suggest that Korea's exports of these commodity groups are ambiguously influenced by the market-power effects of strengthening IPRs across low-income countries.

Within the middle-income group, the coefficients for the development dummy interaction variable $\left(\mathrm{IPR}_{\mathrm{ij}} \times \mathrm{MD}_{\mathrm{jt}}\right)$ in most of the product categories are positive, and ten of them are statistically significant (Fish, Petroleum, Plastics in Primary Forms, Plastics in Non-primary Forms, Chemicals Materials and Products, Leather, Manufactures of Metals, General Industrial Machinery and Equipment, Prefabricated Buildings Sanitary, and Photographic Apparatus). This indicates that stronger protection of IPRs induces Korea's exports to countries in middle-income countries. In addition, this market-expansion effect tends to be stronger in IPR-sensitive industries (e.g., Plastics, Chemical Materials and Products, etc.) where the manufacturing process usually requires significant investments in R\&D. Although, in some product categories the coefficients are negative, they are statistically insignificant (Iron and Steel, Telecommunication, and Other Transport Equipment).

Within the high-income group, the coefficients on the interaction term $\left(\mathrm{IPR}_{\mathrm{jt}} \times\right.$ $\mathrm{HD}_{\mathrm{jt}}$ ) are positive in twenty-seven out of thirty sectors. Although only three of them are statistically significant (Fish, Manufacture of Metals, and Prefabricated Buildings Sanitary), the positive signs could indicate that within high-income countries, the market-expansion effects dominate sectors with the largest export volume. Three sectors register negative signs for the interaction term include Textile Yarn, Iron and Steel, and Telecommunication. However, all of these coefficients are not different from zero.

Based on the above results, we can observe that the market expansion effects are the most prevalent in middle-income countries, followed by high-income countries and finally low-income countries. This result is consistent with evidence that industrial countries with weak IPR regimes tend to import more when their IPR regimes are strengthened. In addition, the coefficients of interaction terms for IPR-sensitive industries are larger than for total exports. This result indicates that Korea's exports of IPR-sensitive product categories are more responsive to IPR enforcement than are Korea's aggregate exports.

\section{CONCLUSION}

This paper has tried to contribute to the existing body of literature in the arena where IPR protection meets trade flows. Using the gravity equation with the random effects model, it analyzes the impacts of IPR protection in foreign countries, grouped by their level of economic development, on Korea's total exports and exports by commodity (at the 1-digit and 2-digit commodity groups). 
Our empirical results are robust. The major findings are summarized as follows. First, since the coefficient on the IPR index is positive and statistically significant in the case of Korea's total exports, we conclude that on average, stronger protection of IPRs in foreign countries (the rest of the world) induces more of Korea's exports, exhibiting the prevalence of market-expansion effects. When the impacts of IPR protection are allowed to differ across sectors, stronger effects are found in IPR-sensitive tech-sectors such as Chemicals, Machines and Transport Equipment, etc.

Second, stronger protection of IPRs induces Korea's exports to all foreign countries regardless of their level of development. The effects are stronger in medium-income and high-income countries, followed by low-income countries. When the impacts of IPR protection are allowed to differ across sectors, again stronger effects are noticed in IPR-sensitive sectors such as Plastics in Primary Forms, Chemicals and Machines, Transport Equipment, etc. Our sectoral results are supportive of the theoretical prediction that the market-expansion effect is likely to be predominant in larger markets with high imitative abilities. In our study, the market-expansion effects are most evident in middle-income countries, followed by high-income countries and finally, low-income countries.

Third, the coefficients on the interaction dummy variables $\left(\mathrm{IPR}_{\mathrm{jt}} \times \mathrm{LD}_{\mathrm{jt}}, \mathrm{IPR}_{\mathrm{jt}} \times\right.$ $\mathrm{MD}_{\mathrm{jt}}$, and $\mathrm{IPR}_{\mathrm{jt}} \times \mathrm{HD}_{\mathrm{jt}}$ ) are negative in some sectors. Although being statistically insignificant, negative parametric estimates could suggest that the strengthening of IPR protection in foreign countries could lead to an ambiguous decrease in Korea's exports of these commodity groups. However, we can conclude that in the case of Korea's exports, the market-power effects have been very minimal and unclear. One possible explanation is that Korea has not exercised market power because of the possible trade diversion effect by foreign countries.

Fourth, the coefficients of the interaction terms for IPR-sensitive industries are larger than for total exports (for example: Plastics in Primary Forms, Chemical Materials and Products, Manufacture of Metals). This result indicates that Korea's exports of IPR-sensitive product categories are more responsive to IPR enforcement than are Korea's aggregate exports.

Finally, the signs of the coefficients on traditional variables suggest that Korea tends to export more to countries with higher levels of GDP and higher degrees of openness to trade, and tends to export less to landlocked countries and countries that are distant from itself.

The implication is that Korea's exports would increase further if appropriate measures are taken in order to strengthen IPR protection in foreign countries. However, these measures must be accompanied by efforts to increase the GDP, improve social infrastructure, and accelerate domestic reforms (openness to trade) in foreign countries as well. Importantly, the strengthening of IPRs would have greatest effect if foreign GDP also rose.

This paper acknowledges its limitations in the sense that the IPR index is 
at the national level, not at the industry level. This is due to the fact that there has been no IPR measurements at the industry level at the time of writing this paper. In addition, the scope of this study only distinguishes domestic imitations and imports from Korea. The analysis in this paper has not focused on the imports of imitations from Korea. This knowledge gap in the existing literature provides rich opportunity for further research. Therefore, the authors strongly suggest that future research should address these interesting issues.

\section{REFERENCES}

Aitken, N. D. 1973. The Effect of the EEC and EFTA on European Trade: A Temporal Cross-section Analysis. American Economic Review 63(5): 881-92. Al-Mawali, N. 2005. Bilateral Intra-Industry Trade Flows and Intellectual Property Rights Protection: First Empirical Evidence. Applied Economic Letters 12: 823-28. Bikker, J. A. 1987. An International Trade Flow Model with Substitution: An Extension of the Gravity Model. KYKLOS 40(3): 315-37.

Brada, J. C., and J. A. Mendez. 1983. Regional Economic Integration and the Volume of Intra-Regional Trade: A Comparison of Developed and Developing Country Experience. KYKLYOS 36(4): 589-603.

Chionis, D., and P. Liargovas. 2002. An Empirical Investigation of Greek-Balkan Bilateral Trade. Eastern European Economics 40(5): 6-32.

Clarete, R., C. Edmonds, and J. S. Wallack. 2003. Asian Regionalism and Its Effects on Trade in the 1980s and 1990s. Journal of Asian Economics 14(1): 91-129.

Co, C. C. 2004. Do Patent Rights Regimes Matter? Review of International Economics 12(3): 359-73.

Deardorff, A. V. 1995. Determinants of Bilateral Trade: Does the Gravity Work in a Neoclassical World? Working Paper \# 5377, NBER.

Doanh, N. K., and Y. Heo. 2007. Impacts of Intellectual Property Right Protection on Trade Flows in ASEAN Countries. Journal of International and Area Studies 14(1): 1-15.

Egger, P. 2000. A Note on the Proper Econometric Specification of the Gravity Equation. Economic Letters 66(1): 25-31.

Endoh, M. 1999. Trade Creation and Trade Diversion in the EEC, the LAFTA and the CMEA: 1960-1994. Applied Economics 31: 207-16.

Endoh, M. 2000. The Transition of Postwar Asia-Pacific Trade Relations. Journal of Asian Economics 10: 571-89.

Falvey, R., N. Foster, and D. Greenaway. 2009. Trade, Imitative Ability and Intellectual Property Rights. Review of World Economics 145(3): 373-404.

Ferrantino, M. J. 1993. The Effects of Intellectual Property Rights on International Trade and Investment. Weltwirtschaftliches Archive 129: 300-331. 
Fink, C., and C. A. Primo-Braga. 2005. How Stronger Protection of Intellectual Property Rights Affects International Trade Flows. In Intellectual Property and Development: Lessons from Recent Economic Research, eds. C. Fink and K. E. Maskus, 19-40. Washington, D. C.: The International Bank for Reconstruction and Development/The World Bank.

Frankel, J. A. 1993. Is Japan Creating a Yen Block in East Asia and the Pacific? In Regionalism and Rivalry: Japan and the United States in Pacific Asia, eds. J. Frankel and M. Kahler. Chicago, CA: University of Chicago Press.

Flam, H., and E. Helpman. 1987. Industrial Policy under Monopolistic Competition. Journal of International Economics 22: 79-102.

Geraci, V. J., and W. Prewo. 1977. Bilateral Trade Flows and Transport Costs. Review of Economics and Statistics 59(1): 67-74.

Glick, R., and A. K. Rose. 2002. Does a Currency Union Affect Trade? The Time Series Evidence, NBER Working Papers 8396, National Bureau of Economic Research.

Grossman, G. M., and E. Helpman. 1991. Innovation and Growth in the Global Economy. MIT Press 61: 1247-80.

Hausman, J. A. 1978. Specification Tests in Econometrics. Econometrica 46: 1251-71.

Helpman, E. 1993. Innovation, Imitation and Intellectual Property Rights. Econometrica 61: 1247-80.

Hoekman, B. M., and M. M. Kostecki. 2001. The Political Economy of the World Trading System: The WTO and Beyond. New York: Oxford University Press. Jung, M.-H. 2007. The Effects of Interaction of the Foreign Intellectual Property Rights and Imitation Ability on the Export Patterns of IT Industrial Sectors in Korea. The Journal of Korea Research Society for Customs 8(1): 231-58 (in Korean).

Kang, H.-J., and K. Y. Park. 2006. The Effects of Foreign Intellectual Property Rights (IPRs) on the Export Volume of Korea. Korea Trade Review 31(4): 5-31 (in Korean).

Lee, J.-E., and E. Mansfield. 1996. Intellectual Property Right Protection and U.S. Foreign Direct Investment. Review of Economics and Statistics 78(2): 181-86. Linnemann, H. 1966. An Econometric Study of International Trade Flows. Amsterdam: North Holland Publishing Co.

Liu, W. H. and Y. C. Lin. 2005. Foreign Patent Rights and High-tech Exports: Evidence from Taiwan. Applied Economics 37: 1543-55.

Martinez-Zarzoso, I. 2003. Gravity Model: An Application to Trade between Regional Blocs. Atlantic Economic Journal 3 (2): 174-87.

Martinez-Zarzoso, I., and F. Nowak-Lehmann. 2003. Augmented Gravity Model: An Empirical Application to Mercosur-European Union Trade Flows. Journal of Applied Economics 6(2): 291-316.

Maskus, K. E. 1998. The International Regulation of Intellectual Property. 
Weltwirtschaftliches Archiv 134(2): 186-208.

Maskus, K. E. 2000. Intellectual Property Rights in the Global Economy. Washington, D. C.: Institute for International Economics.

Maskus, K. E., and D. Eby-Konan. 1994. Trade-Related Intellectual Property Rights: Issues and Explanatory Results. In Analytical and Negotiating Issues in the Global Trading System, eds. A. V. Deardorff and R. M. Stern. Ann Arbor, NI: University of Michigan Press.

Maskus, K. E., and M. Penubarti. 1995. How Trade-related Are Intellectual Property Rights? Journal of International Economics 39: 227-48.

Maskus, K. E., and M. Penubarti. 1997. Patents and International Trade. In Quiet Pioneering: Robert M. Stern and His International Economic Legacy, eds. K. Maskus, P. Hooper, E. E. Leamer, and J. D. Richardson. Ann Arbor, MI: University of Michigan Press.

Musila, J. W. 2005. The Intensity of Trade Creation and Trade Diversion in COMESA, ECCAS and ECOWAS: A Comparative Analysis. Journal of African Economies 14(1): 117-41.

Oguledo, V. I. and C. R. Macphee. 1994. Gravity Models: A Reformulation and an Application to Discriminatory Trade Arrangements. Applied Economics 26: $107-20$.

Oh, K.-Y., and J. I. Won. 2005. The Effects of Patent Rights on International Trade: Evidence of Korea. Journal of International Trade and Industry Studies 10(1): 19-42 (in Korean).

Park, W. G., and J. C. Ginarte. 1997. Determinants of Patent Rights: A Cross-national Study. Research Policy 26: 283-301.

Park, W. G. 2008. International Patent Protection: 1960-2005. Research Policy 37: 761-66.

Peridy, N. 2005. The Trade Effects of the Euro-Mediterranean Partnership: What Are the Lessons for ASEAN Countries. Journal of Asian Economics 16: 125-39.

Primo-Braga, C. A., and C. Fink. 1997. The Economic Justification for the Grant of Intellectual Property Rights: Patterns of Convergence and Conflict. In Public Policy and Global Technological Integration, eds. M. A. Frederick and D. J. Gerber. Dordrecht. Netherlands: Kluwer Academic Publishers.

Raballand, G. 2003. Determinants of the Negative Impact of Being Landlocked on Trade: An Empirical Investigation Through the Central Asian Case. Comparative Economic Studies 45: 520-36.

Rafiquzzaman, M. 2002. The Impact of Patent Rights on International Trade: Evidence from Canada. The Canadian Journal of Economics 35(2): 307-30.

Rapp, R. T., and R. P. Rozek. 1990. Benefits and Costs of Intellectual Property Protection in Developing Countries. Journal of World Trade 24: 75-102.

Sapir, A. 1981. Trade Benefits under EEC Generalized System of Preferences. European Economic Review 15(3): 339-55. 
Schwartz, M. 1991. Patent Protection through Discriminatory Exclusion of Imports. Review of Industrial Organization 6: 231-46.

Seyoum, B. 1996. The Impact of Intellectual Property Rights on Foreign Direct Investment. Columbia Journal of World Business 31: 51-9.

Segerstrom, P., T. C. A. Anant, and E. Dinopoulus, 1990. A Schumpeterian Model of the Product Life Cycle. American Economic Review 80: 1077-91.

Seyoum, B. 1996. The Impact of Intellectual Property Rights on Foreign Direct Investment. Columbia Journal of World Business 31(1): 50-9.

Sherwood, R. 1997. Intellectual Property Systems and Investment Stimulation: The Rating of System in Eighteen Developing Countries. IDEA 37(2): 261-370. Smith, P. J. 1999. Are Weak Patent Rights a Barrier to U.S. Exports? Journal of International Economics 48: 151-77.

Smith, P. J. 2001. How Do Foreign Patent Right Affect U. S. Exports, Affiliate Sales, and Licenses? Journal of International Economics 55: 411-39.

Smith, P. J. 2002. Patent Rights and Trade: Analysis of Biological Products, Medicinals and Botanicals, and Pharmaceuticals. American Journal of Agricultural Economics 84(2): 495-512.

Srivastava, R., and T. T. Green. 1986. Determinants of Bilateral Trade Flows. Journal of Business 59(4): 623-40.

Taylor, S. M. 1993. TRIPs, Trade, and Technology Transfer. Canadian Journal of Economics 26: 625-38.

Taylor, S. M. 1994. TRIPs, Trade, and Growth. International Economic Review 35(2): 361-81.

Wen-Hsien, L., and L. Ya-Chi. 2005. Foreign Patent Right and High-Tech Export: Evidence from Taiwan. Applied Economics 37(13): 1543-55.

Yang, C.-H., and Y. J. Huang. 2009. Do Intellectual Property Rights Matter to Taiwan's Exports? A Dynamic Panel Approach. Pacific Economic Review 14(4): 555-78. 


\section{APPENDICES}

Appendix 1. List of Countries in the SAMPle

\begin{tabular}{|c|c|c|c|c|c|}
\hline Order & Countries & Order & Countries & Order & Countries \\
\hline 1 & Algeria & 32 & Haiti & 63 & Philippines \\
\hline 2 & Argentina & 33 & Honduras & 64 & Poland \\
\hline 3 & Australia & 34 & Hong Kong & 65 & Portugal \\
\hline 4 & Austria & 35 & Hungary & 66 & Romania \\
\hline 5 & Bangladesh & 36 & India & 67 & Saudi Arabia \\
\hline 6 & Belgium & 37 & Iran & 68 & Senegal \\
\hline 7 & Benin & 38 & Ireland & 69 & Singapore \\
\hline 8 & Bolivia & 39 & Israel & 70 & South Africa \\
\hline 9 & Brazil & 40 & Italy & 71 & Spain \\
\hline 10 & Bulgaria & 41 & Jamaica & 72 & Sri Lanka \\
\hline 11 & Cameroon & 42 & Japan & 73 & Sudan \\
\hline 12 & Canada & 43 & Jordan & 74 & Sweden \\
\hline 13 & Chile & 44 & Kenya & 75 & Switzerland \\
\hline 14 & China & 45 & Liberia & 76 & Syrian Arab Republic \\
\hline 15 & Colombia & 46 & Madagascar & 77 & Taiwan \\
\hline 16 & Congo & 47 & Malawi & 78 & Tanzania \\
\hline 17 & Costa Rica & 48 & Malaysia & 79 & Thailand \\
\hline 18 & Cyprus & 49 & Malta & 80 & Togo \\
\hline 19 & Denmark & 50 & Mauritania & 81 & Trinidad \& Tobago \\
\hline 20 & Dominican Rep. & 51 & Mexico & 82 & Tunisia \\
\hline 21 & Ecuador & 52 & Morocco & 83 & Turkey \\
\hline 22 & Egypt & 53 & Nepal & 84 & Uganda \\
\hline 23 & El Salvador & 54 & Netherlands & 85 & United Kingdom \\
\hline 24 & Fiji & 55 & New Zealand & 86 & United States \\
\hline 25 & Finland & 56 & Nicaragua & 87 & Uruguay \\
\hline 26 & France & 57 & Nigeria & 88 & Venezuela \\
\hline 27 & Gabon & 58 & Norway & 89 & Vietnam \\
\hline 28 & Germany & 59 & Pakistan & 90 & Zaire \\
\hline 29 & Ghana & 60 & Panama & 91 & Zambia \\
\hline 30 & Greece & 61 & Paraguay & 92 & Zimbabwe \\
\hline 31 & Guatemala & 62 & Peru & & \\
\hline
\end{tabular}




\section{APPENDIX 2. SUMMARY OF STATISTICS}

\begin{tabular}{lccccc}
\hline \multicolumn{1}{c}{ Variable } & Count & Mean & Std. Dev. & Minimum & Maximum \\
\hline $\operatorname{lnE} \mathrm{ijt}_{\mathrm{jt}}$ & 368 & 2.288 & 0.971 & 0.316 & 4.792 \\
$\operatorname{lnGDP}_{\mathrm{it}}$ & 368 & 5.686 & 0.171 & 5.421 & 5.898 \\
$\operatorname{lnGDP}_{\mathrm{jt}}$ & 368 & 4.623 & 0.902 & 2.130 & 7.095 \\
$\operatorname{lnPOP}_{\mathrm{it}}$ & 368 & 1.660 & 0.019 & 1.632 & 1.682 \\
$\operatorname{lnPOP}_{\mathrm{jt}}$ & 368 & 1.192 & 0.600 & 0.000 & 3.116 \\
$\operatorname{lnDIST}_{\mathrm{ij}}$ & 368 & 3.949 & 0.247 & 2.983 & 4.292 \\
OPEN $_{\mathrm{jt}}$ & 368 & 0.684 & 0.978 & 0.074 & 12.729 \\
$\mathrm{LOCK}_{\mathrm{i}}$ & 368 & 0.109 & 0.312 & 0.000 & 1.000 \\
$\mathrm{IPR}_{\mathrm{jt}}$ & 368 & 2.926 & 1.072 & 0.590 & 4.880 \\
$\mathrm{LD} \times \mathrm{IPR}$ & 368 & 0.597 & 1.031 & 0.000 & 3.760 \\
$\mathrm{MD} \times \mathrm{IPR}$ & 368 & 1.189 & 1.469 & 0.000 & 4.540 \\
$\mathrm{HD} \times \mathrm{IPR}$ & 368 & 1.140 & 1.853 & 0.000 & 4.880 \\
\hline
\end{tabular}

NOTE: Statistical results. 


\section{ENDNOTES}

${ }^{1}$ For example, Maskus (2000) noted that theoretical models do not clearly predict the impacts of variable patent rights on trade volumes. Much depends on local market demand, the efficiency of imitative production, and the structure of trade barriers. Also important are the reactions of imperfectly competitive firms. Thus, a clear picture can emerge only from empirical studies.

2 Industry-level analysis is particularly advantageous because the effects of IPR protection on trade can be washed out at the aggregate level.

${ }^{3}$ While a large number of studies using the gravity model to predict trade flows employ cross-sectional data, the use of panel data allows us to capture the relationship between IPRs and trade over a longer period of time, to control for the overall business cycle and disentangle the time-invariant country-specific effects (Egger 2000), and to control for unmeasured country- and time-specific heterogeneity (Co 2004).

4 Many studies have attempted to measure IPR cross-nationally; among them are Rapp and Rozek (1990), Seyoum (1996), and Sherwood (1997).

5 Industrial countries have strong imitative abilities. Therefore, to a large extent, their markets might be served by imitated goods. Stronger IPR regimes would reduce the level of local infringement, and imitated goods are replaced by foreign patented goods, generating a market-expansion effect.

6 Initially, markets of these countries might already be served by foreign exporting firms. Since the imitative abilities in these countries are often weak, the strengthening of IPR regimes in these countries would not create a market-expansion effect that is large enough to outweigh the market-power effect.

7 The dependent variable $\ln (1+$ Eijt $)$ enables us to include observations of zero measurable exports (Musila 2005).

8 It depends on whether the absorption effect or the economies of scale effect is dominant (Aitken 1973; Bikker 1987; Brada and Mendez 1983; Endoh 1999; Endoh 2000; Linnemann 1966; Martinez-Zarzoso and Nowak-Lehmann 2003; Oguledo and Macphee 1994; Srivastava and Green 1986; Sapir 1981).

9 Psychic distance indicates the lack of familiarity with another country's laws, institutions, and habits (Drysdale and Garnaut 1982). All of these factors reflect the cost of international transactions of goods and services and are expected to affect trade negatively (see, for example, Al-Mawali 2005; Clarete et al. 2003; Deardorff 1995; Geraci and Prewo 1977; Martinez-Zarzoso 2003).

10 Rafiquzzaman (2002) and Smith (2002) also used development dummy variables that interact with IPRs.

11 Our classifications are based on the World Bank's categorization.

12 Co (2004) also largely relies on the random-effects model because, with only one exporter, the fixed-effects model would exclude time-invariant variables such as the distance and land-lock.

${ }^{13}$ The random-effects model requires that $\mu_{\mathrm{ij}} \sim\left(0, \sigma_{\mu}^{2}\right)$ and $\mathrm{u}_{\mathrm{ijt}} \sim\left(0, \sigma_{\mu}^{2}\right)$, and that $\mu_{\mathrm{ij}}$ is independent of $\mathrm{u}_{\mathrm{ijt}}$; further, the explanatory variables have to be independent of $\mu_{\mathrm{ij}}$ and $\mathrm{u}_{\mathrm{ijt}}$ for all cross-sections (ij) and time-periods $(t)$. The advantage of the random-effects model is that both time-series and cross-sectional variations are used.

14 The index takes on a value between zero (no protection) and five (maximum protection). The higher the numbers are, the stronger the protection of IPR is.

15 According to the Hausman, we cannot reject the null hypothesis that there is no misspecification for the random effects model. Therefore, the random effects model is more appropriate in this case. 